METAMODERN SENSIBILITY

IN JENNI FAGAN'S 'THE WAKEN'
Brno Studies in English

Volume 47, No. 1, 2021

ISSN 0524-6881 | e-ISSN 1805-0867

https://doi.org/10.5817/BSE2021-1-13

\title{
SOŇA ŠNIRCOVÁ
}

\begin{abstract}
Jenni Fagan is a critically acclaimed author whose works explore marginalized girlhood in Scottish cultural contexts. "The Waken" depicts the story of a young girl brought up by a violent father on a Hebridean island in which a Stevensonian representation of evil acquires a feminist flavour. Through allusions to Stevenson's Gothic, Fagan draws on the antisyzygy element in Scottish literature but instead of reproducing an idea of duelling polarities within one entity, she uses binary oppositions in a polysyzygiacal way. This article shows that multiple alignments and plural connections of Fagan's polysyzygy indicate her text's participation in a metamodern sensibility. Creating a metamodern simultaneity in which a feminist deconstruction of patriarchal narratives coexists with the employment of the reconstructive potential of myth, Fagan's narrative presents a more dialogical approach to male literary traditions than the works of postmodern feminists. ${ }^{1}$
\end{abstract}

Key words

Jeni Fagan; 'The Waken'; Stevensonian Gothic; feminism; metamodern sensibility

\section{Introduction}

A wide range of recent studies of postmillennial literary works (for example, those of Brooks and Toth 2007, Eshelman 2008, Holland 2013, Huber 2014, Kušnír 2015, Sawa 2020) have drawn attention to an increasing number of new trends that suggest the emergence of a post-postmodernist aesthetic. This new aesthetic includes approaches that may range from "an ironic critique of traditional postmodern literature" (Kušnír 2015: 19) through the performatist modes that force postmodern sceptics into believing the unbelievable (Eshelman 2008: 37 ), the "reconstructive shift" that replaces postmodern parodic deconstructions with attempts to "reconstruct meaningful communication" (Huber 2014: 218) to the metamodern neo-romanticism that has been identified in "a wide variety of art forms and a broad diversity of styles, across media and surfaces" (Vermeulen and Akker 2010: 8). The neo-romantic sensibility is present not only in contemporary artists' re-discovery of the uncanny, the enchanted and the haunted that turns "the commonplace into a site of ambiguity, of mystery, and unfamiliarity" (Vermeulen and Akker 2010: 10) but also in their explorations of the reconstructive potential of myth: "This post-postmodern ethos, eschewing both the 


\section{Soňa Šnircová}

naïve metaphysical systems of the past as well as the superficial materialism of postmodernity, has occasioned a project of reconstruction - one in which new myths and paradigmatic models are now being artfully crafted for the twenty-first century" (Demsey 2014: n. pag.). To metamodern artists the re-appropriation of myth opens the possibility to rebel against "postmodern kitsch and commodity" (Demsey 2014: n. pag.) and reintroduce the idea of the transcendent that suggests the existence of a deeper meaning of life, ignored by postmodernism. The metamodern desire for meaning and depth in life is often related to the need to reconstruct the sense of unity with nature that has been lost due to the destructive effects of postmodern civilisation.

As Irmtraud Huber has observed, female authors may experience greater difficulties in appropriating the fantastic for reconstructive purposes since the fantastic has been powerfully associated with a "feminist project of subversion of patriarchal structures and narratives" (2014: 233). Due to these difficulties, the use of myth in the narratives of contemporary female writers may result in a "metamodern simultaneity" 2 in which a feminist (postmodernist) deconstruction of patriarchal discourses coexists with the construction of a dialogical relation with a male literary tradition. An example of metamodern simultaneity can be found in the work of Jenni Fagan, one of the outstanding voices in postmillennial Scottish literature.

Jenni Fagan's novels Panopticon (2012) and The Sunlight Pilgrims (2016) have earned her critical acclaim, a place in the 2013 Granta list of the best young British novelists and the title of Sunday Herald Culture Awards Scottish Author of the Year for 2016. Her short story "The Waken" was shortlisted for the BBC National Short Story Award in 2017. Despite their significant superficial differences, all three of these works share Fagan's focus on the exploration of marginalized girlhood in Scottish cultural contexts: a girl trapped within the Scottish care system that leaves her alone in her struggle to evade "neo-patriarchal containment" (Jones 2015: 1) in Panopticon; a transgendered girl struggling with her identity in a hostile small-village community in a post-apocalyptic Highlands in The Sunlight Pilgrims, and a girl enduring her father's abusive behaviour on an isolated Hebridean island in "The Waken".

\section{Metamodern Sensibility in "The Waken"}

While Panopticon relates to feminist Foucaldian concerns with power structures of modern society and the cli-fi novel The Sunlight Pilgrims is rooted in global discourse on climate change, "The Waken" shows the strong influence of local literary traditions: a Stevensonian exploration of evil mingles with stories about selkies, the mythical creatures of the folklore of the Scottish islands. Through allusions to Stevenson's Gothic, Fagan draws on the antisyzygy element in Scottish literature, infusing her text with tension between duelling polarities: good/ evil, rational/irrational, civilized/barbarian, Christian/pagan, nature/culture, global/local, patriarchal/feminist... However, instead of merely reproducing Stevenson's exploration of what Maureen M. Martin describes as "a conflict between 
rational and romantic, canny and reckless, moralistic and violent, an idea of duelling polarities within one entity" (2009: 84-85), Fagan's use of binary oppositions results in polysyzygy, a concept that Stuart Kelly defines as-the "multiple alignments, plural connections, a web of interlinked ideas and words" (Kelly 2009: 12). The polysyzygiacal character of Fagan's text suggests that Scottish literature has entered a new phase in which concerns with duelling polarities have lost their potential to form a productive response to the postmillennial world. It reveals that Fagan has joined the contemporary female Scottish writers who "have recognised Caledonian Antisyzygy as merely one of the multitude of possible organising principles of their creative work" and whose text reflect the "polysyzygy, which corresponds to a Bakhtinian polyphony of a multitude of voices entering in incessantly shifting interactions and creating a harmony in their own right" (Jelínková 2019: 26).

The participation of major Scottish female authors in Caledonian Antisyzygy through the revival of the Gothic tradition has been widely recognized. As Ema Jelínkova and her colleagues have shown (Jelínková 2014a), this participation has produced various narratives about grotesque hybrid identities which are resonant with Hoggian and Stevensonian doppelgänger motifs, often reemployed for feminist purposes. The popularity of the Gothic among Scottish (and other) female authors arises from its potential to undermine the power of dominant discourses: "The general subject of the Gothic literature is otherness in the broadest senseincluding the condition of being the other (read female) sex-and depending on the specific treatment of otherness in the work, it may serve either to reinforce or, more often, to subvert the established social order" (Gregorová 2014: 101). For several decades, feminist rewritings of male literary works have been a major trend in female postmodernist literature: Angela Carter's Gothic version of Charles Perrault's classic collection of fairy-tales (Carter 1979), Valerie Martin's rewriting of Stevenson's The Strange Case of Dr Jekyll and Mr Hyde from a housemaid's perspective (Martin 1990) and Emma Tennant's feminist appropriations of the Jekyll and Hyde story and the story of Hogg's Justified Sinner (Tennant 1989, 1979) are some of the best known examples of the trend. In creating characters that problematize male visions of the world, authors such as Carter, Martin or Tennant promote a feminist politics aimed at the deconstruction of patriarchy. Tennant's relating of the female Jekyll/Hyde transformation to an oppressive patriarchal politics of beauty (Anténe 2014: 47) or the subversion of the male predator/female victim binary in her version of Private Memoirs and Confessions of a Justified Sinner (Jelínková 2014b: 97) are apt examples of feminist twists on the Gothic classics.

Jenni Fagan's use of the Gothic tradition and Scottish folklore in "The Waken" draws in many respects on the subversive power of the fantastic that has played a major role in feminist deconstructions of patriarchal discourses. However, Fagan's work with the fantastic also bears traces of a metamodern, neo-romantic sensibility that, according to Vermeulen and Akker (2010) rejects deconstruction, irony and pastiche and turns to affect, authenticity, ethical concerns and myth. Just as in Stevenson's and Hogg's famous narratives, Scottish folklore forms a crucial part of the local literary tradition that informs Fagan's short story. As Milena 


\section{Soňa Šnircová}

Kaličanin observes, Scottish folklore not only forms a crucial element of Scottish cultural heritage but also retains an "enormous cultural and literary impact on modern Scottish identity" (2018: 23) and its re-emergence in contemporary narratives may signal an increasing resistance among authors to the devastating effect of globalisation on local identity. ${ }^{3}$

In one respect, Fagan's incorporation of folklore into "The Waken" can be related to the conflict between the global and the local that plays an important role in the story, set as it is in a small isolated community. Yet, her choice of the specific folkloric creature, the selkie folk, reveals that her representation of the conflict is saturated with a neo-romantic sensibility. Unlike the sirens that signify the deadly peril of the sea, selkies are sea creatures that can shed their sealskin and transform into beautiful women capable of bearing human children and performing the role of a human wife. They are often presented as tragic figures, constantly longing for that which they do not have: when they are seals, they long to be humans, but when they are humans, they want to swim in the sea. Fagan's short story however draws more on the romantic potential of selkie folk-tales, the selkies' ability to fall in love with humans. Although the employment of folkloric or mythic characters is a common feature in female postmodern texts, they usually function as tools of feminist resistance against the romantic, perceived as being complicit in the patriarchal oppression of women. ${ }^{4}$ As I will demonstrate later, Fagan uses selkies to a very different, even entirely opposite, purpose.

Fagan's treatment of the classic Gothic text also differs significantly from more typical feminist approaches of authors such as Carter, Martin or Tennant. As Seth Abramson (2016: n. pag.) notes, intertextuality in postmodern literature commonly acquires "the form of parody or pastiche-the referencing of another text in order to, through the distance between the two texts, insert a social critique or ironic commentary". In metamodern literature, "the uses of intertextuality are much more flexible: often brief; only intermittently substantive; ambivalent about whether they are readily recognized by every member of audience; sometimes so distorted or jumbled up by the author as to even be unrecognizable as citations; intended as an idiosyncratic expression of the author's network of associations rather than the establishment of a broader canon of associations". While Tennant's Two Women of London: The Strange Case of Ms Jekyll and Mrs Hyde offers a typical example of a postmodernist approach to a popular classic, Fagan's "The Waken" appears as a metamodern response to Stevenson's less well-known work "Thrawn Janet".

"Thrawn Janet" is a short story about a newly graduated parish minister who arrives to enlighten a superstitious moorland community but whose personal encounter with the devil transforms him from a man of education into a crude and savage figure thwarted by the experience of horror who spreads an atmosphere of terror among his parishioners. Although the story includes a black male figure that corresponds with the common image of the devil in Scottish folk narratives (Parsons 1946: 561), its main Gothic element is the eponymous heroine: a village witch whose grotesquely animated dead body is the most horrifying evidence of the devil's presence.

"Thrawn Janet" has not attracted the wider readership which The Strange Case of Dr Jekyll and Mr Hyde enjoys, possibly due the fact that a major part of the nar- 
rative is written in Scots dialect and this is deepened further by the story's focus on obscure beliefs in witches possessed by the devil rather than the more modern interest in the duality of human nature. Even Stevenson himself acknowledged the apparent lack of universality in the story that is largely concerned with the revival of local folk narratives. However, despite Stevenson's claim that "It is true only historically, true for a hill parish in Scotland in old days, not true for mankind and the world" (Stevenson quoted in Parsons 1946: 570), the narrative does in fact encompass wider geographical and social connotations. As Coleman O. Parsons's study reveals, "Thrawn Janet" can be directly related to the historical persecutions of witches described in "the annals of lowland parishes" and its local colouring does not suppress the fact that "witchcraft itself had more than Caledonian currency" (1946: 570). In addition, Stevenson's use of a woman-possessedby-the devil image for sensational purposes relates the text to the wider body of the patriarchal myths about women being more disposed to succumb to the devil.

Although "The Waken" bears signs of a feminist critique of this traditional positioning of women in the good/evil binary, its response to "Thrawn Janet" goes beyond a parodic rewriting of Stevenson's Gothic narrative. At first appearance, Fagan's contemporary story about Jessie, a girl who murders her tyrannical father and completes her revenge after her fantastic transformation into a goat by feeding on her father's corpse, bears little resemblance to the story of a witch's persecution by a village and her subsequent destruction by the devil. Nonetheless, there are certain parallels between "The Waken" and "Thrawn Janet" which indicate that the latter text can be interpreted as an intertext: both stories are set in isolated Scottish villages which are hidebound by traditional ways of life that resist the influence of the modern world; they also share an atmosphere of terror which is spread through the community by a crude man, a central character possessed by the devil and a female victim of patriarchal authority; both texts also give crucial roles to supernatural folkloric characters and include the central motif of a transformation that brings about substantial changes to lives of their protagonists. On the other hand, Fagan's intertextual allusions are so subtle that a reductive reading of "The Waken" as a straightforward ironic commentary on "Thrawn Janet" could be problematic. On the contrary, one could be more inclined to perceive the relationship between the two texts as an example of Abramson's definition of metamodern intertextuality, marked by "ambivalence, distortion and the author's idiosyncratic network of associations" (Abramson 2016: n. pag.). This metamodern form of intertextuality forms the basis of Fagan's response to "Thrawn Janet", combining a critique of the patriarchal core of Stevenson's Gothic narrative with a neo-romantic interest in the metaphysical aspects of his work. Moving beyond the limits of feminist deconstructions of patriarchal binary thought, Fagan enters the sphere of "metamodern dialogue" that has replaced "postmodern dialectics" (Ambramson 2017: n. pag.). As Seth Abramson explains, the metamodern dialogue rejects the postmodern assumption that "every situation involves just two primary opposing forces - which do battle until one emerges victorious and the other is destroyed" and emphasizes the "areas of overlap between contesting opinions" while at the same time preserves an awareness of "differences between parties and positions" (2017: n. pag.). It is a shared concern with the metaphysical aspects 


\section{Soňa Šnircová}

of human existence that creates such a degree of overlap between "Thrawn Janet" and "The Waken" and their competing representations of the role of women within the good/evil binary.

"The Waken" covers the few days following the death of the protagonist's father, providing a detailed account of the ancient rite-of-passage rituals performed by the inhabitants of a small village: the local women's cleansing and dressing of the body in burial robes, the vigil and feasting during the "Dead Days" and finally the funeral that goes grotesquely wrong: in order to avoid a conflict with another funeral procession, the coffin is dropped off a cliff into the sea but the dead body remains stuck on the rocks which only goats can reach. The grotesque dominates the entire story narrated as it is from the perspective of the daughter who has poisoned her brutal and feared father and who "just sat there, with her feet up, in his armchair - reading a book he loathed for a good half-an-hour before she let anyone else to know [about his death]"(n.pag.). The claustrophobic atmosphere of an isolated community terrorised by an evil man intensifies the Stevensonian flavour of the narrative in which Jessie's worry that "not even the devil would want her father's soul" mingles with the community's belief that his soul has been taken by the devil long before his actual death.

By placing Jessie and her father at the centre of her story Fagan recreates the dynamics of the relationship that drives the narrative in "Thrawn Janet": the destruction of an evil character results in the transformation of the character who participates in the destruction. While Reverend Soulis, who has inadvertently caused Janet's death by forcing her to renounce the devil, emerges from the course of events as a radically different person, Jessie's wilful murder of her father brings about her equally radical transformation. However, "The Waken's" imitation of "Thrawn Janet's" dynamics includes some important elements of subversion. By changing the gender of the character "possessed" by the devil, Fagan adds a feminist perspective to Stevenson's metaphysical examination of good and evil:

Not keen on reading, her father. Not interested in opinions (other than his own), found women idiotic (useful mostly only for cleaning and bedding) and men weak (less-than-himself-in-every-way), and regularly declared all children to be - total arseholes. His use of language was delicate as his fist and laced with a similar fury...Her mother had grown smaller and frailer under her father's sneer and loathing, his fist and his envy... (n.pag.)

Although at first appearance this tyrannical father figure might seem to be the opposite of the educated, benign young minister that we encounter at the beginning of Stevenson's story, both men in fact represent patriarchal authority, the protective power of which can easily turn into the power to destroy. After Reverend Soulis has rescued Janet from the mobbing of the local women, he exercises his right to demand her renunciation of the devil, an act for which she pays with her life. Jessie's father exercises the same right to demand things from the women in his charge although his behaviour, in marked contrast to that of Soulis's attempt to save Janet's soul, lacks any good intentions whatsoever. On the contrary, 
his deeds suggest the presence of an arbitrary, inhuman evil that highlights the character's separation from the village and turns him into something more than a grotesque symbol of patriarchal power:

He'd spread his seed among this community.

Fought husbands.

Burned down the village barn.

Teased children.

Kicked bulls.

Spent many nights toasting the lack of police anywhere these shores. (n.pag.)

His fascination with disintegration (he leaves sheep heads on the counter until "they bubble with flesh all rotten and blue") strengthens his association with the devil and even the Dead Days rituals become, as Jessie observes, a form of exorcism that the small community performs.

While the superficial differences between the benign minister and the horrible tyrant paradoxically draw attention to the similarity of their positions in patriarchal power structures, the initial subtle parallel between Jessie and Janet leads the reader, over the course of the story, to distinguish an important difference. The first signs of Jessie's physical changes - her growing of horns and cloven hooves within a few nights of the vigil - suggest that Jessie is her father's daughter and an heiress of his devilish nature. "If a man as horrible as her father could have been so unsettled by her presence what did that mean for her soul?" ponders Jessie by the side of her father's corpse; just like Janet who is treated as a threat to the village, she also provokes the fear of the small community: "Jessie had picked her way among the members of the Waken, noting their glances toward her, their worry that she might stay among them and find a boy and seduce him and bear children and bring another male MacCrae back to this island when this one had just gone" (n.pag.).

However, while Janet's otherness arises from her transgressions of social taboos (she is a single mother, does not take communion and, in general, does not behave as a God-fearing woman ought to), Jessie's otherness acquires a more tangible form. She is the only girl in the village who does not have her selkie mother's ability to turn into a seal. Instead, after the patricide, she transforms into a goat which comes across her father's body, stranded on the cliffside, and begins to feed on his dead body. Drawing on Stevenson's grotesque plot twist (contrary to the Reverend Soulis's belief, Janet's transgressive behaviour is in fact a result of her pact with the devil), Fagan again enriches Stevenson's metaphysics with a feminist perspective: Jessie's horns and cloven hooves are not signs of her devilish nature but instead elements of the corporeal transformation that allows her to complete the destruction of the hated patriarch. However grotesque and barbaric Jessie's act may appear, it does nonetheless possess an ethical dimension-it is an act of revenge (for her mother's suffering) and a punishment for all of the bad deeds which her father has committed over the course of his life. Due to his violent behaviour, Jessie's father has lost any connection with humanity and 


\section{Soňa Šnircová}

its civilized ways and has thus earned his fate since "bad men deserve to be eaten by goats" (n.pag.).

It is the ethical dimension of Fagan's short story that both supports and transcends her feminist critique of patriarchy when it appears as a part of a supra-human order of things in which nature and humanity exist in a mythical union. While employing an allusion to the Christian myth that associates the goat with the devil, Fagan at the same time places Jessie's transformation within the context of pagan myths about selkies. In Fagan's story, all of the village women are seal wives who bear children with the islanders. Symbolically they represent the dissolution of the nature/culture binary not only through their willing and active participation in the cultural rituals that sustain the human community on the island but also through their ability to transition freely between their animal and human states. Unlike their counterparts from traditional stories who remain trapped in the human world after their skin has been stolen, Fagan's selkies are able to enjoy both their human and animal lives. Similarly, Jessie's transformation into a goat is an escape into an animal form that helps her cope with her human existential crisis. In contrast to the Stevensonian Gothic that Fagan's short story revives, animality and humanity do not function in the text as duelling polarities within a single entity, but instead as two aspects of being that help Jessie to transcend the limits of her existence. Jessie's means of achieving a unity with nature (her transition to the goat state) grants her a new-found strength and leaves her ready to face the big world beyond the island that she intends to join after her expected return to human form.

If the outside world in Stevenson's short story is aligned with an enlightened rationalism imported into an isolated village by the young minister, in Fagan's story the outside world is presented as a source of corruption: Jessie's father is an incomer to the community and his excessively violent behaviour is incongruous with the more innocent ways of the islanders; Jessie imagines that on the mainland she may encounter men equally bad or even worse than her father, and her own transformation into a goat, an animal with far more ambiguous connotations than a seal, suggests the corruption of her mother's bloodline with her father's seed. Just as the Stevensonian exploration of the good/evil polarity acquires a contemporary, feminist, dimension in Fagan's story, her employment of the Romantic innocent savage/corrupted civilization binary is aligned to the contemporary conflict between the global and the local. The people who visit Jessie's village hoping to "see the aurora borealis or the many kinds of eagle" represent the globalized civilization that treats the local world as an open air museum and the island as an attraction where tourists can "witness how nature still work[s]" (n.pag.). The tourists' perception of the villagers as a primitive community is a sign of the corrupted ways of modern society. They have lost touch with traditional ways of living, and this results in their inability to perceive the unity of culture and nature in which the island's community still participates. Although eager to observe the island's wildlife, the tourists are unable to spot the "private and mistrusting" selkies and they are too detached (both physically and mentally) to understand local forms of (seemingly barbaric) justice. When a group of tourists sailing on a whale-watching boat is too far off to spot what a wild goat on 
the cliff is feasting on, Jessie nonetheless hopes that their cameras "clearly caught the blood on her lips, on her horns, that these photographs would go out into the world as some kind of a warning to tyrannical, stupid, lumbering selfish men whose element knew no boundary" (n. pag).

\section{Conclusion}

Although the feminist tone of the concluding section of "The Waken" once again suggests the text's participation in the feminist deconstructions of male classics, Fagan's revival of Stevensonian Gothic bears strong signs of the new sensibility that Vermeulen and Akker (2010) have aligned with metamodern trends in art. Metamodernism, according to Vermeulen and Akker, reflects the exhaustion of endless postmodern deconstructions, irony and pastiche and finds "its clearest expression in an emergent neoromantic sensibility [...] the return of the Romantic, whether as style, philosophy, or attitude" (2010: 8). As they further explain, "If these [metamoderm] artists look back at the Romantic it is neither because they simply want to laugh at it (parody) nor because they wish to cry for it (nostalgia). They look back instead in order to perceive anew a future that was lost from sight" (2010: 12). Thus, for example, metamodern visual artists often employ "traditional mythic iconography" to frame their critique of the negative developments of the postmillennial world, such as the ecological crisis, and “to counter postmodernism's total emancipation from transcendent paradigms” (Demsey 2014: n. pag.). Fagan's treatment of the myth in "The Waken" appears to fulfil the same dual purpose.

Instead of offering a straightforward ironic deconstruction of "Thrawn Janet", "The Waken" enters into a dialogical relationship with Stevenson's Gothic narrative. The villager's perception of Jessie's father as a devilish figure is not simply rejected as the product of superstitious minds but instead exists side by side with the text's symbolic treatment of the character as a personification of patriarchal evils. Jessie's final claim that tyrannical and selfish men would become "far more fatal and dangerous than any pure evil" if left "unchallenged or without vengeance" (n. pag) does not exclude the possibility that such an evil could come to pass. In fact, the text supports the possible existence of metaphysical evil with the other supernatural occurrences in the otherwise realistic setting of the story: the presence of mythical selkies and Jessie's own mystical metamorphosis.

Although in the case of Jessie's transformation into a corpse-eating goat, a mythical element is employed for an undeniably feminist purpose - the premonition that male tyranny will not remain unpunished - it also reflects a neo-romantic attempt at the "re-appropriation of culture through nature" that Vermeulen and Akker (2010: 8) identify as one of the defining features of the metamodern sensibility. Jessie's temporary escape into oneness with nature functions not only as a tool of grotesque revenge but also as a form of empowerment that may have a constructive effect on her social relations in the human world: "It was a certainty in her that by later morning she would return to her other form just as the seal wives and when she did she'd go out there, across the water to the mainland and never return to these shores" (n.pag.). ${ }^{5}$ 


\section{Soňa Šnircová}

Fagan's appropriation of the selkie myth, on the other hand, presents the clearest example that her narrative transcends both patriarchal and feminist explorations of duelling polarities. While Stevenson uses the Scottish folkloric figure of the "black man" to highlight the human/inhuman binary (the human appearance of the figure disguises his inhuman devilish nature), Fagan's employment of selkies suggests the possibility of the dissolution of binary oppositions: the selkies are simultaneously human and inhuman since they can move freely between their human and animal forms. Replacing the motif of entrapment that dominates in traditional versions of the myth with the selkie's willing and active participation in the human world, Fagan moves away from feminist critiques of patriarchal representations of women in male mythopoeia. Her representation of selkies is far from that of an image of a feminist rebellion. They are depicted as dutiful wives who play an important role in the preservation of the community's traditional ways of life: "Seven women left their homes ready to help her cleanse and prepare the body and host the Waken. Jessie opened the door to each of them knowing they were not there for her father but for her - God and decency [...] It was women who eased the passage between the twin rites (life and death)" (n.pag). The willing participation of the selkies in the pre-funeral rituals and the vigil at the loathed patriarch's deathbed suggests that they are related not so much to the conflict between the feminist and the patriarchal, but to the metaphysics of life and death that transcends all social conflicts.

Thus both the traditional folkloric myths and Stevenson's more modern text serve as more than mere objects of a feminist deconstruction of patriarchal narratives, functioning instead as building blocks in the construction of Fagan's metamodern polysyzygiacal narrative; a narrative that draws attention not only to the persisting presence of the conflict between patriarchal and feminist worldviews, but also to other pressing issues of the contemporary world: the rift between globalizing civilisation and traditional local cultures, the increasing yearning of modern people for a revived unity with nature, and the failure of postmodern rationality to deal with the metaphysical aspects of human existence.

\section{Notes}

1 This research has been supported by VEGA 1/0447/20 The Global and the Local in Postmillennial Anglophone Literatures, Cultures and Media, granted by the Ministry of Education, Research and Sport of the Slovak Republic. Soňa Šnircová is a research collaborator at the University of the Balearic Islands Research Group in British and Comparative Cultural Studies (BRICCS).

$2 \quad$ Seth Abramson (2017) describes "simultaneity" as one of the fifteen basic principles of metamodernism, claiming that earlier understandings of metamodernist thinking (see e.g. Vermeulen and Akker 2010) as an "oscillation" between "opposing states of thought, feeling, and being" has been replaced by "the idea that the metamodern self does not move between differing positions but in fact inhabits all of them at once".

3 As Kaličanin notices, recent years have seen rising voices of protest that warn against the continuing "sacrilege" of reducing national myths to "a profitable tourist sensation" and urge the realization of their importance in the formation and continuation of national and individual identities (2018: 23). 
4 Angela Carter's and Sara Maitland's deconstructions of such romantic fairy tales as "Beauty and The Beast", "Snow White", or "Cinderella" illustrate this trend in feminist literature. See Carter's "The Courtship of Mr Lyon", "The Tiger's Bride" and "The Snow Child" in The Bloody Chamber (1979) and Maitland's "The Wicked Stepmother's Lament" in Angel Maker (1996).

5 This is in a clear contrast with Angela Carter's well-known feminist version of the same motif. Carter's heroine's metamorphosis into an animal also functions as an escape from the oppressive structures of patriarchal society but it suggests no possibility of a return into the human form. See the Beauty's metamorphosis into a tiger in "The Tiger's Bride".

\section{References}

Abramson, Seth (2016) Five More Basic Principles of Metamodernism 05/14/2015. Updated May 12, 2016. Accessed on 19 February 2020. https://www.huffpost.com/entry/ five-more-basic-principle_b_7269446.

Abramson, Seth (2017) Ten Basic Principles of Metamodernism. 04/27/2015. Updated Dec 06, 2017. Accessed on 19 February 2020. https://www.huffpost.com/entry/tenkey-principles-in-met_b_7143202.

Anténe, Petr (2014) Women Crossing Borders-the Gothic and the Fantastic. In: Jelínková, Ema (ed.) Scottish Women Writers of Hybrid Identity. Olomouc: Palacký University, 37-64.

Brooks, Neil and Josh Toth. (eds.) (2007) The Mourning After. Attending the Wake of Postmodernism. Amsterdam, New York: Rodopi.

Carter, Angela (1979) Bloody Chamber and Other Stories. London: Penguin Books.

Demsey, Brendan (2014) [Re]construction: Metamodern "Transcendence" and the Return of Myth. Notes on Metamodernism. Posted on October 21, 2014. Accessed on $16 \mathrm{Au}-$ gust 2018. https://www.metamodernism.com/2014/10/21/reconstruction-metamodern-transcendence-and-the-return-of-myth/.

Eshelman, Raoul (2008) Performatism, or the End of Postmodernism. The Davies Group Publishers.

Fagan, Jenni (2013) The Panopticon. London: Windmill Books.

Fagan, Jenni (2016) The Sunlight Pilgrims. London: Windmill Books.

Fagan, Jenni (2017) The Waken. The BBC National Short Story Award 2017. Introduced by Joanna Trollope. Comma Press. Kindle.

Gregorová, Markéta (2014) Afterword: Charting New Territories, Forging New Identities. In: Jelínková, Ema (ed.) Scottish Women Writers of Hybrid Identity. Olomouc: Palacký University, 100-104.

Holland, Mary (2014) Succeeding Postmodernism: Language and Humanism in Contemporary American Literature. London: Bloomsbury.

Huber, Irmtraud (2014) Literature after Postmodernism: Reconstructive Fantasies. Palgrave Macmillan.

Jelínková, Ema (ed,) (2014a) Scottish Women Writers of Hybrid Identity. Olomouc: Palacký University.

Jelínková, Ema (2014b) Anglo-Scottish and Scot-English Prose by Female Writers. In: Jelínková, Ema (ed.) Scottish Women Writers of Hybrid Identity. Olomouc: Palacký University, 93-99.

Jelínková, Ema (2019) The Concept of "Caledonian Polysyzygy" in Kate Atkinson's Short Story Collection Not the End of the World. In SKASE Journal of Literary and Cultural Studies 1 (1), 22-33. Accessed on 20.3. 2021. http://www.skase.sk/Volumes/SJLCS01/ pdf_doc/03.pdf. ISSN 2644-5506. 
Jones, C (2015) "Femininity in Crisis": The Troubled Trajectory of Feminism in Laura Hird's Born Free and Jenni Fagan's The Panopticon. Contemporary Women's Writing 9 (3), 385-400. https://doi.org/10.1093/cww/vpv007

Kaličanin, Milena (2018) Uncovering Caledonia. An Introduction to Scottish Studies. Newcastle upon Tyne: Cambridge Scholars Publishing.

Kelly, Stuart (2009) Introduction. In Kelly, Stuart (ed.) Headshook. London: Hachette, 1-14.

Kušnír, Jaroslav (2015) Postmodernism and After: New Sensibility, Media, Pop Culture, and Communication Technologies in Anglophone Literatures, Nitra: ASPA.

Maitland, Sara (1996) Angel Maker: the short stories of Sara Maitland. New York: Henry Holt.

Martin, Maureen M. (2009) The Mighty Scot: Nation, Gender, and the Nineteenth-century Mystique of Scottish Masculinity. Albany: SUNY.

Martin, Valerie (1990) Mary Reilly. London: Black Swan.

Parsons, Coleman O. (1946) Stevenson's Use of Witchcraft in "Thrawn Janet”. Studies in Philology 43 (3), 551-571.

Sawa, Magdalena (2020) "We Need to Rediscover the Living Body": Gabriel Josipovici's Metamodern Project in Goldberg: Variations. Brno Studies in English 46 (2), 261-279.

Stevenson, Robert Louis (1881) Thrawn Janet In Dr Jekyll and Mr Hyde Ẽ The Merry Men and Other Tales and Fables. London: Wordsworth, 1993.

Tennant, Emma (1979) The Bad Sister. London: Pan Books.

Tennant, Emma (1989) Two Women of London: The Strange Case of Ms Jekyll and Mrs Hyde. London: Faber \& Faber.

Vermeulen, Timotheus and Robin van den Akker (2010) Notes on Metamodernism. Journal of Aesthetics and Culture 2 (1), 1-14. https://doi.org/10.3402/jac.v2i0.5677.

SOŇA ŠnirCová is Associate Professor in literary studies in the Department of British and American Studies in the Faculty of Arts at the University of Pavol Jozef Šafárik in Košice, Slovakia. She is the author of the books Girlhood in British Coming-of-Age Novels: The Bildungsroman Heroine Revisited (2017), Feminist Aspects of Angela Carter's Grotesque (2012), the textbook Realism, Modernism, Postmodernism: Five Modern Literary Texts in Contexts (2015) and the co-editor of the books Growing up a Woman: The Private/Public Divide in the Narratives of Female Development (2015) and Postmillennial Trends in Anglophone Literatures, Cultures and Media (2019). Her academic interests include theory of the grotesque, British women's literature, the female Bildungsroman, feminism, postfeminism, performatism and metamodernism.

Address: doc. Mgr. Soňa Šnircová, PhD, Department of British and American Studies, Faculty of Arts, Pavol Jozef Šafárik University in Košice, Moyzesova 9, 04001 Košice, Slovakia. [sona.snircova@upjs.sk] 